\title{
Thoracoscopic closure of patent ductus arteriosus in children
}

\author{
P Kołtowski ${ }^{1 *}$, D Patkowski ${ }^{2}$, C Augustyn ${ }^{1}$, G Sharma ${ }^{1}$, A Wesnerowicz ${ }^{1}$, R Clchoń ${ }^{1}$ \\ From 23rd World Congress of the World Society of Cardio-Thoracic Surgeons \\ Split, Croatia. 12-15 September 2013
}

\section{Background}

Patent ductus arteriosus is a common congenital disorder (10\% of congenital disorders). Ductus Botalli closure is the realm of invasive cardiology. Inability to perform ductus Botalli closure with percutaneous methods causes, that administration of indomethacin or surgery are nowadays treatment of choice. The aim is to present an alternative in treatment with minimally invasive surgery, such as video-assisted thoracoscopic closure of PDA.

\section{Methods}

We admitted 38 patients aged between 11 days and 7 years (65\% of patients $\leq 1$ year), with a weight between $700 \mathrm{~g}$ and $24,5 \mathrm{~kg}$. During the procedure we insert trocar with optic $5 \mathrm{~mm}$ into the pleural cavity in positioning on the right side through 4-5 intercostal space on the anterior axillary line. Secondly $3 \mathrm{~mm} 2$ tools are inserted through 3rd and 6th intercostal spaces on midaxillary line. We visualize posterior mediastinum and identify ductus Botalli. We close it with titanium clips in sizes depending on how large PDA is. We used $5 \mathrm{~mm}$ clips in 27 cases $(8 \mathrm{~mm}, 10 \mathrm{~mm}$ in others). Average length of thoracoscopic procedure was about 40 minutes (15 minutes min,90 minutes max). After surgery we do ultrasound control.

\section{Results}

The procedure was successful in 31 patients. Positive result of complete closure was confirmed by ultrasound diagnostic, done after the procedure. In other 6 cases, post-surgery ultrasound revealed ineffective closure and in 1 case the procedure was impossible to perform because of bad conditions of visualization. In 1 case we repeated thoracoscopic closure. In other 6 cases lateral thoracotomy

\footnotetext{
* Correspondence: p.koltowski@medinet.pl

${ }^{1}$ Lower Silesian Heart Centre Medinet, Wrocław, Poland

Full list of author information is available at the end of the article
}

was necessary. Total hospitalization time (thoracoscopic closure of patients only) varied between 2 and 5 days, while in classic surgical method it lasted on average about 7 days.

\section{Conclusions}

Reduced invasiveness of this method seems to be more adequate than traditional lateral thoracotomy. We would like this method to be considered as an alternative treatment to the traditional lateral thoracotomy when other less invasive methods are not effective.

\section{Authors' details}

${ }^{1}$ Lower Silesian Heart Centre Medinet, Wrocław, Poland. ${ }^{2}$ Pediatric Surgery and Urology Department, Wroclaw Medical University, Wrocław, Poland.

\section{Published: 11 September 2013}

doi:10.1186/1749-8090-8-S1-O244

Cite this article as: Kołtowski et al:: Thoracoscopic closure of patent ductus arteriosus in children. Journal of Cardiothoracic Surgery 2013 8(Suppl 1):0244.

Submit your next manuscript to BioMed Central and take full advantage of:

- Convenient online submission

- Thorough peer review

- No space constraints or color figure charges

- Immediate publication on acceptance

- Inclusion in PubMed, CAS, Scopus and Google Scholar

- Research which is freely available for redistribution
C Biomed Central

C 2013 Kottowski et al; licensee BioMed Central Ltd. This is an Open Access article distributed under the terms of the Creative Commons Attribution License (http://creativecommons.org/licenses/by/2.0), which permits unrestricted use, distribution, and reproduction in any medium, provided the original work is properly cited. 